\title{
LIBERDADE E RELIGIÃO: REFLEXÕES KANTIANAS SOBRE A NÃO COERCITIVIDADE, A VERACIDADE E A PUBLICIDADE NA RELAÇÃO ENTRE RELIGIÃO E POLÍTICA
}

\author{
FREEDOM AND RELIGION: KANTIAN REFLECTIONS ON NON- \\ COERCIVITY, TRUTHFULNESS AND PUBLICITY ON THE \\ RELATIONSHIP BETWEEN RELIGION AND POLITICS
}

\author{
JOEL TIAGO KLEIN \\ (Universidade Federal do Rio Grande do Norte, Brasil)
}

\begin{abstract}
RESUMO
De acordo com a filosofia kantiana existem três princípios que deveriam regular a forma como a política se relaciona com a religião, quais sejam, o princípio da não-coercitividade da crença religiosa; a exigência moral da veracidade nas profissões de crença e a incapacidade de máximas com conteúdo religioso se conformarem com o princípio político-jurídico da publicidade. O objetivo deste artigo é apresentar, explicar e justificar a aplicação desses três princípios com relação à religião e indicar como eles poderiam ajudar a resolver problemas políticos e morais com respeito à intolerância religiosa que continua a assolar a sociedade contemporânea.

Palavras-chave: Religião. Intolerância. Não-corcitividade. Veracidade. Publicidade.
\end{abstract}

\begin{abstract}
According Kantian philosophy there are three principles that should regulate how politics relates to religion, namely, the principle of non-coercivity of religious belief, the moral requirement of truthfulness in professions of belief and the inability of maxims with religious content to conform itself with the political and legal principle of publicity. The objective of this paper is to present, explain and justify the application of these three principles with regard to religion and to indicate how they could help to solve political and moral issues regarding religious intolerance that continues to plague contemporary societies.
\end{abstract}

Key words: Religion. Intolerance. Non-coercivity. Truthfulness. Publicity.

A intolerância e a perseguição religiosa são alguns dos problemas mais sérios e delicados que a filosofia moral precisa enfrentar. Infelizmente trata-se de um problema muito antigo e de difícil solução. Isso ocorre porque a religião engloba uma visão de mundo bastante abrangente e excludente, a qual se torna incompatível com outras visões de mundo e, muitas vezes, até mesmo incapaz de conviver com elas.

A possibilidade da acomodação pacífica de diversas crenças religiosas em um mesmo país ou mesmo sobre o planeta depende também, mesmo que não apenas, da existência de uma filosofia robusta o suficiente para estabelecer que as asserções das religiões não sejam equivalentes a verdades ou a conhecimentos objetivos do mundo. Em outras palavras, a possibilidade teórica da tolerância e da liberdade religiosa depende de uma filosofia que defenda a existência de uma única racionalidade válida, uma única verdade a respeito daquilo que se conhece e a respeito daquilo que é a moral, mas uma racionalidade tal que não seja 
demasiada estreita e determinada por aspectos históricos e culturais. Uma filosofia que defenda o contrário, ou seja, uma filosofia que defenda o pluralismo da racionalidade humana acaba tendo de se calar frente à intolerância e a perseguição religiosa estabelecida de modo unilateral a partir de valores e crenças de uma determinada religião, visto que a única forma de impedir que uma religião com uma visão de mundo abrangente e excludente acredite legitimamente que possa se impor sobre as outras é tendo outra visão de mundo ainda mais abrangente que seja capaz de sustentar que nenhuma asserção da religião é a expressão da verdade. Portanto, para se evitar que uma religião defenda de modo legítimo a existência de um direito de impor a sua verdade e seus valores morais é preciso ter uma filosofia capaz de sustentar que toda e qualquer religião histórica não pode ser considerada como portadora da verdade acerca do conhecimento e da moralidade o que, por sua vez, significa dizer uma verdade, ou ainda, significa dizer algo sobre como funciona a racionalidade humana e o que é o conhecimento teórico e prático, independente da determinação histórica e cultural. Segue-se assim, a meu ver, que apenas uma filosofia de caráter universalista pode garantir teoricamente a liberdade e a pluralidade de religião.

A filosofia kantiana é a expressão de uma filosofia universalista que pretende oferecer condições para justificar e legitimar a liberdade religiosa, assim como para destruir os fundamentos racionais que pudessem legitimar qualquer tipo de intolerância e perseguição religiosa. O próprio Kant sentiu as consequências desse tipo de perseguição que teoricamente condenou e combateu por ocasião da publicação do seu livro A religião nos limites da simples razão. Mas fazia muito que ele refletia sobre questões relacionadas com a intolerância religiosa, sobre o caráter da crença religiosa e o status teórico e moral da própria religião. Já nas suas lições sobre ética, mais especificamente na Vorlesung über Moralphilosophie anotada segundo Collings encontra-se uma cartografia conceitual das diferentes atitudes de intolerância relacionadas com questões de religião.

Para Kant, a tolerância, em geral, é caracterizada como uma compassividade em relação àquilo que se considera um erro nos outros, enquanto que o intolerante é aquele que não consegue suportar a imperfeição dos outros sem ódio e, por isso, ele próprio também não pode ser suportado sem ódio. "Disso se segue que a tolerância é um dever universal de humanidade. Os homens têm muitos defeitos reais e perceptíveis, por isso cada um precisa suportar os defeitos dos outros" (V.MoCollings, AA 27, 453), ${ }^{1}$ ou ao menos, aquilo que eles consideram um defeito nos outros. Em assuntos de religião, ser tolerante significa: 
objeto de ódio o fato de alguém ter assumido por verdadeira religião aquilo que para minha religião é um erro. Eu não devo odiar homem algum, mesmo se ele for o causador deliberado de algum mal ou erro na medida em que ele pensar estar fazendo o bem. Assim ele não pode ser um objeto de ódio. O ódio teológico (odium theologicum) é uma espécie de ódio da alma que se inicia quando o teólogo transforma os objetos da sua vaidade em assuntos de Deus. Trata-se de um ódio que se sustenta sobre o orgulho de, sendo um professor das coisas de Deus, pretender também ser alguém que recebeu a autoridade para governar os homens em seu nome. Joga-se o ódio religioso (odium religiosum) em alguém quando se acredita que os seus erros são uma alta traição à divindade, fazendo passar os erros de religião por crimina laesae majestatis divinae. Ora, quem inverte o julgamento dos outros, apresentando-o de um modo distinto e retirando dele muitas consequências para com isso concluir que se tratam de crimina laesae majestatis divinae, esse indivíduo é alguém que joga ódio religioso sobre outros. Esse que faz isso é um consequentiarius, e atribui ao juízo dos outros algo que de forma alguma pensaram (...). O crimina laesae majestatis divinae é um absurdo [Unding] e ninguém comete tal coisa. $\mathrm{O}$ ortodoxo considera, segundo a sua opinião, que a sua religião deva ser necessariamente universal. (...) A ortodoxia não pode obrigar ninguém. (...) $\mathrm{O}$ espírito de perseguição silencioso é aquele que persegue os homens pelas costas, falando deles e atribuindo a eles o nome de ateísta: trata-se de um espírito de perseguição desprezível. O espírito de perseguição sutil é quando se persegue alguém de opinião distinta não com ódio, mas mesmo assim com uma certa repulsa. O espírito de perseguição que surge pela honra de Deus combate contra tudo e não distingue nem benfeitor ou amigo, nem pai ou mãe, mas vê como um mérito poder queimar os outros por honra a Deus. Em questões de verdade de religião não se pode utilizar nenhuma forma de violência, mas razões. A verdade se defende por si mesma e um erro se prolonga por mais tempo se contra ele for usado violência. A liberdade de investigação é o melhor instrumento da verdade. (V.MoCollings, AA 27, 453ff. Tradução própria).

Nessa passagem encontra-se de forma bastante embrionária três teses mutuamente relacionadas que Kant irá desenvolver minuciosamente, ainda que de modo esparso, em obras futuras. Essas três teses tem uma consequência direta sobre o significado e a legitimidade da liberdade de religião e estão assentadas em três princípios, a saber, o princípio da nãocoercitividade, o princípio da veracidade e o princípio da publicidade. A forma como se compreende esses princípios tem, por sua vez, uma consequência direta sobre como o Estado e a política podem e devem lidar com a religião, especialmente quando surge o problema da intolerância e da perseguição religiosa. O objetivo deste artigo é apresentar, explicar e justificar a aplicação desses três princípios com relação à religião e pensar como eles poderiam ajudar a resolver problemas políticos e morais com os quais a sociedade contemporânea ainda se depara.

\section{Religião e não coercitividade}

A possibilidade de se estabelecer algo como crença depende de que se possua um conhecimento acerca daquilo que constitui as características daquilo que é o conhecimento e daquilo que o distingue dos objetos da crença e da mera opinião. Se não for possível 
estabelecer um limite qualitativo entre aquilo que somente pode ser objeto de crença e aquilo que pode ser conhecimento, então as fronteiras entre ambas as formas de assentimento [fürwahrhalten] se tornam embotadas e tudo se torna potencialmente ao mesmo tempo objeto de crença e objeto de conhecimento. Mas como não se poderia então saber quando se trata de um ou de outro, segue-se que tudo é conhecimento e tudo é crença, simultaneamente e em constante tensão. Como toda crença religiosa acaba apresentando os seus próprios critérios sobre aquilo que se caracteriza como sendo uma crença boa, correta e verdadeira, segue-se que toda crença assume, da sua perspectiva, que é melhor que as outras. Sob a hipótese de não se poder apresentar um conhecimento, isto é argumentos racionais que possam e devam ser aceitos universalmente, então não se pode solucionar teoricamente um conflito no qual grupos de crenças distintas com pretensão de verdade e universalidade colidem, logo, segue-se que o único elemento que resta para se saber qual dos grupos tem a verdade do seu lado é a força. Tem-se assim uma espécie de salto mortal da razão, pois quando não é mais a razão que decide sobre como resolver os impasses entre os homens, a força toma lugar da razão (cf. TP, AA 08: 306). Sessam os argumentos e a tentativa de entendimento e se pega em armas.

Assim, a filosofia kantiana sustenta que o único modo de se pensar em uma forma de convivência pacífica entre diferentes grupos com crenças distintas é quando se aceita que cabe a filosofia estabelecer definitivamente, por meio de uma crítica da razão pura, aquilo que, por um lado, pode ser objeto de conhecimento e, por conseguinte, quais são os critérios que devem ser preenchidos para que algo seja considerado como tal, e aquilo que, por outro lado, deve ser considerado um objeto de crença e as características que o ato de acreditar precisa possuir para que seja condizente com a atitude de um ser racional.

Uma das principais consequências da filosofia crítico-transcendental é que a religião e tudo aquilo que se refere aos assuntos de crença são incapazes de possuir força coercitiva. A não coercitividade se refere tanto ao âmbito teórico, quanto prático. No que se segue analisase detalhadamente cada um desses aspectos.

A não coercitividade teórica das asserções ligadas a assuntos de religião se deve a uma separação de gênero ou espécie e não apenas de grau entre uma asserção dotada de valor de verdade e uma asserção que só pode possuir valor de crença. Se os temas de Deus, imortalidade da alma ou da liberdade aspirassem ao estatuto de conhecimento teórico, então, quando eles se chocassem com os conhecimentos apresentados pelas ciências, teriam que ser considerados como falsos. A única possibilidade da religião aspirar alguma legitimidade racional é quando ela permanece e aceita permanecer no campo da crença. Como Kant anuncia no prefácio à segunda edição da Crítica da razão pura, ele "t $\mathrm{t}$ e]ve de suprimir o saber 
para obter lugar para a fé" $(K r V, \mathrm{~B} \times x x)$.

Segundo a Dedução transcendental das categorias, para que algo seja considerado objeto de conhecimento possível, tal objeto deve por princípio estar adequado a nossa forma de conhecer, ou seja, ao modo como operam nossas faculdades e as suas formas e conceitos $a$ priori. Assim, por exemplo, o conceito de causalidade deve poder ser aplicado a um evento em questão. Nesse caso, é uma condição do uso das categorias que elas se aplicam somente aquilo que nos seja dado na intuição (cf. $K r V$, B147-149). Porém, ao ser dado na intuição, tal objeto também estaria submetido às condições formais da nossa intuição e daquilo que constitui a forma do fenômeno, a estrutura geral da natureza estabelecida pelas categorias. Nesse caso, por exemplo, ou um evento/objeto dado na intuição pode necessariamente ser conhecido como sendo causado por outro evento/objeto anterior e, portanto, como não sendo causa de si próprio, ou tal objeto não pode ser dado na intuição e, nesse caso, não seria um objeto cognoscível. Se, por um lado, algo que se autodenominasse Deus aparecesse como um objeto na nossa intuição, então se poderia ter certeza de que não se trata de Deus, pois poderíamos rastrear quais foram as suas causas e ele não seria um ser não causado. Se, por outro lado, Deus não pode ser dado como fenômeno, então ele não pode ser considerado um objeto de conhecimento possível.

Portanto, a filosofia transcendental estabelece que Deus, liberdade e imortalidade são objetos que ficam fora do nosso campo da experiência possível e portanto não podem ser considerados objetos de conhecimento teórico possível. Essa delimitação não ocorre com base numa análise exaustiva dos objetos presentes no campo da experiência possível, os quais podem serem infinitos e, por isso, seriam incapazes de ser abarcados completamente. Nesse sentido, poder-se-ia dizer que Deus vive no céu, mas ao se chegar à Lua ou em Marte e ele não estando Deus lá, se diria que ele vive em uma estrela mais distante e assim, sucessivamente. Mas não é dessa forma que o campo do conhecimento possível é estabelecido. Uma crítica da razão pura não é a avaliação dos diferentes objetos de conhecimento, mas uma avaliação da própria faculdade da razão (cf. $K r V$, B xxi-xxix). É com base na análise e avaliação de como funciona a nossa faculdade de conhecimento que se conclui quais são as características de um objeto de conhecimento possível e se reconhece que Deus não pode ser um tal objeto.

Os objetos de crença e os objetos de opinião são assim objetos de natureza distinta. Os objetos de opinião ainda não são conhecimentos, mas podem vir a sê-lo na medida em que certas condições sejam cumpridas, quais sejam, serem empiricamente constatáveis, em outras 
palavras, se apresentarem como fenômenos. Já os objetos de crença ou fé não podem jamais se transformar em conhecimentos teóricos, pois por sua própria definição, contrariam a estrutura da natureza. Assim, a existência de vida extraterrestre inteligente é um objeto de opinião, a qual pode ser mais ou menos provável ou plausível, mas, a princípio pode ser algum dia comprovada uma vez que se tenha uma intuição desses seres ou de seus vestígios em outros planetas, por exemplo. Já a existência de Deus ou de Deuses, por sua própria definição, não permite que sejam jamais objetos intuídos sob pena de não mais serem os objetos alegados.

A crença, enquanto distinta do conhecimento, não possui por isso coercitividade teórica. Isso significa que é impossível apresentar argumentos e razões suficientes para que alguém se sinta racionalmente compelido a aceitar determinada crença. Mas é isso exatamente o que acontece com o conhecimento. É algo fora de questão que " $4+3=7$ " não seja algo que se precise acreditar, mas um conhecimento objetivo. Se um aluno somar " $4+3=6$ " sua conta será considerada errada, se alguém fizer tal conta em um processo de indenização ou pagamento de salário será obrigado a se corrigir. Se alguém aponta para um fóssil de dinossauro, pode-se fazer uma teoria sobre como ele ficou conservado ou de que espécie ele era, mas que se trata um fóssil de algum animal extinto a milhares de anos é um fato objetivo, algo que pode ser conhecido objetivamente. Da mesma forma acontece quando se apresenta diversos fósseis de hominídeos pré-históricos, ou seja, podem haver discordâncias sobre detalhes a respeito de como aconteceu a evolução natural, quais foram todas as suas etapas ou o que lhe impulsionou, mas que houve uma evolução natural, isso é um fato objetivo, um juízo verdadeiro. Nesse contexto, sustentar que a educação pública das crianças deva aceitar simultaneamente nas escolas o ensino tanto do criacionismo, quanto do evolucionismo como teorias igualmente dotadas de plausibilidade teórica e como sendo conhecimento é algo simplesmente descabido, uma insensatez.

Não interessa se alguns indivíduos ou se culturas inteiras alegam ou mesmo fazem o contrário. Não se trata de uma perspectiva subjetiva, ou seja, com o quanto de fervor ou intensidade alguém ou um grupo se apega a determinada crença ou mesmo se isso pode efetivamente ser feito ou se já foi feito anteriormente. Trata-se aqui de uma questão de legitimidade. Mesmo que se tratasse de uma crença universalmente compartilhada, ainda assim, ela não deveria ser tratada como conhecimento e ensinada como se fosse tal. Qualquer um que se dispusesse a avaliar de modo imparcial os fatos e argumentos reconheceria e deveria reconhecer que há uma diferença entre uma asserção do tipo "o átomo é composto de prótons e elétrons" e asserções do tipo "Deus criou o mundo em sete dias", "Uma mulher há 
dois mil anos atrás concebeu uma criança sem ter tido contato com o sêmen humano", "Um homem, alegadamente filho de Deus, há dois mil anos subiu aos céus", ou seja, "um homem voou sem a ajuda de nenhuma máquina", “a minha alma é imortal”, ou "minha alma já reencarnou diversas vezes, seja na forma animal ou humana" etc...etc... Qual a diferença? Obviamente, também não se pode ver a olho nu átomos e elétrons, mas com base em diversos experimentos, com controle de variáveis e que podem ser replicados, percebe-se determinados fenômenos que só podem ser compreendidos como efeitos de determinados elementos, ou seja, não há nenhuma outra explicação que possa ser, de forma minimamente razoável, uma explicação concorrente. Nenhuma das asserções do segundo tipo sequer permite a possibilidade de percepção de algo semelhante, não pode ser replicada e, por isso, não pode ser considerada como teoricamente coercitiva.

Talvez se pudesse alegar ainda que as ciências fazem usos de princípios que não são propriamente conhecimentos, mas pressuposições que se vinculam intrinsecamente com a atuação dos cientistas, as quais também estão estreitamente ligadas com a religião. Há aqui um ponto, porém colocado de modo bastante retórico e superficial, a saber, apelando-se apenas a uma analogia entre princípios que na realidade largamente diferem entre si. Assim, há uma grande diferença entre assumir que os produtos da natureza se especificam gradualmente, que a natureza não dá saltos ou que na natureza está tudo bem ordenado tal como se fosse produto de um sábio intelecto e as pressuposições de uma religião, as quais em geral precisam de um Deus pessoal ou de vários Deuses pessoais. Como o próprio Kant chama a atenção, as ciências empíricas realizam algumas suposições que poderiam sugerir algum vínculo com a religião, mas que, ao se analisar com maior atenção e detalhe, percebese que tais suposições feitas algumas vezes pelos cientistas jamais entram elas próprias como hipóteses a serem comprovadas ou asserções que reivindicam o estatuto de conhecimento. $\mathrm{Na}$ verdade, elas são apenas pressupostos regulativos que ajudam na formulação de hipóteses, ${ }^{2}$ as quais, para que sejam consideradas conhecimento, precisam ser comprovadas por experimentos, os quais, por sua vez, sempre precisam resultar e se apoiar em dados empiricamente mensuráveis. Porém, aqueles pressupostos regulativos, eles mesmos, não entrem como hipóteses a serem comprovadas. ${ }^{3}$

Já a não-coercitividade prática da crença religiosa pode ser distinguida, por um lado, a partir da perspectiva ética e, por outro lado, da perspectiva do direito. Da perspectiva ética, as crenças religiosas não conseguem ser coercitivas nem como fundamento da moral, nem como uma consequência da moral. Inicia-se com os problemas envolvidos com a perspectiva das 
crenças religiosas serem o fundamento da moralidade.

Toda moralidade religiosa sustenta-se no conceito ontológico ou teológico de perfeição. A versão moral baseada no conceito teológico de perfeição afirma que a moralidade ocorre quando o sujeito busca adequar as suas ações segundo um modelo derivado de uma vontade divinamente perfeita. Nesse caso, como nós não podemos acessar intuitivamente a perfeição da vontade divina nos resta duas possibilidades, ou a compreendemos a partir daquilo que consideramos em nós como o mais nobre, isto é, o conceito de boa vontade, mas nesse caso caímos em um grosseiro círculo vicioso (pois extraímos desse conceito apenas o que nós mesmos lá havíamos colocado), ou conceberíamos o conceito de perfeição baseado em uma vontade divina que faria "das propriedades da ambição de honra e domínio, ligadas às imagens terríveis do poderio e da vingança, o fundamento de um sistema dos costumes exatamente oposto à moralidade" (GMS, AA 04: 444) Em outras palavras, os indivíduos que agem buscando entrar no paraíso ou fugir do inferno não podem ser considerados morais, pois suas ações não são nada mais do que ações egoístas sustentadas numa inclinação imediata. Já o conceito ontológico de perfeição, que pode ser encontrado em determinadas crenças religiosas, padece de outro problema, a saber, permanece sempre como uma ética heterônoma e não universal, a qual não consegue ordenar nada de forma categórica e imediata. Numa ética heterônoma o imperativo é condicionado, a saber, "se e porque se quer este objeto, tem-se que proceder deste ou daquele modo", ou seja, "a vontade não se dá a lei a si mesma, mas é sim um impulso estranho que lhe dá a lei a ela por meio de uma disposição natural do sujeito acomodada à receptividade desse mesmo impulso." (GMS, AA 04: 444). Note-se que de antemão um indivíduo precisa querer determinado modelo para que ele possa se sentir moralmente compelido a agir de determinado modo, mas não há nada que o compila moralmente a escolher em primeiro lugar tal modelo de perfeição e não outro, ou seja, uma justificativa que compila de modo racional e universal para que se aceite determinado modelo de perfeição em detrimento de outro. Por isso, tal ética somente pode operar com imperativos hipotéticos. De todo modo, voltando-se agora a questão do modelo ontológico de perfeição associado a uma religião, segue-se que tal modelo é normativo apenas para quem de antemão escolheu determinada crença, mas não há nada que possa constranger moral e racionalmente para aquela crença em questão. Portanto, enquanto fundamento da ética, todas as crenças religiosas são incapazes de serem moralmente coercitivas.

As crenças religiosas também não se tornam coercitivas como consequência da moralidade autônoma. É sabido que Kant tenta vincular à sua teoria moral uma reflexão que conduz a uma religião racional, ou a uma religião nos limites da simples razão, mas o real 
significado e a justificativa de Kant para esse passo argumentativo é bastante sinuoso e complicado, além de não ser importante para o tema deste artigo. ${ }^{4} \mathrm{O}$ que é relevante aqui é a tese de Kant da impossibilidade da crença ser moralmente ordenada, ou seja, a crença não é uma consequência necessária do imperativo categórico. Essa relação de consequência pode ser entendida em dois sentidos, a saber, de um lado da perspectiva da teoria moral, isto é, na medida em que a própria consciência da lei moral envolveria imediatamente uma consciência vinculada ao postulado de Deus e da imortalidade da alma (fundamentos de quase todas as religiões) e, por outro lado, de uma perspectiva prático moral, isto é, que o imperativo categórico ordenasse uma religião universal.

Da perspectiva da teoria moral, pode-se dizer que, para Kant, essa não se apresenta como uma possibilidade argumentativa legítima, pois isso minaria a própria autonomia da vontade. Ao contrário, para Kant toda crença em um Deus é impossível de ser moralmente ordenada. Isso quer dizer que, dado que a realização do sumo bem não está em nosso poder, ele "não é, pois, do mesmo modo praticamente necessário como o dever", isto é, "eu posso perfeitamente abstrair da possibilidade ou inexequibilidade dos fins que me obrigo a promover de acordo com aquela lei (...) como de uma coisa que nunca estará completamente em meu poder, a fim de somente considerar aquilo que é do foro do meu fazer." (KU, AA 05: 471) Quer dizer, "se temos em vista apenas as ações, não precisamos dessa crença [no sumo bem]" (Log, AA 09: 69n), ou ainda, "não precisamos [da crença no sumo bem] para agir segundo leis morais, pois estas são dadas pela razão prática apenas." (Log, AA 09: 68n) Disso se pode concluir que não é necessário ter a crença na realização do sumo bem (a qual envolve os postulados de Deus e da imortalidade da alma) para que se possa agir moralmente. Essa impossibilidade da crença ser imposta faz com que ela, distintamente da lei moral, seja um ato da escolha do arbítrio dos indivíduos. Por não se poder necessitar ninguém através de razões morais ou teóricas a respeito de um objeto da crença, a formulação correta é "estou moralmente certo de que existe um Deus", mas não que "Deus existe", nem que "é moralmente certo que existe um Deus". ( $K r V$, B 857) Em outras palavras, a moralidade pode ser um fundamento moralmente subjetivo para se acreditar em um Deus bondoso e criador do mundo, mas jamais pode ser um fundamento moral objetivo, isto é, jamais pode envolver qualquer tipo de coercitividade moral. Portanto, um ateu não só pode ser moral, como é imoral considerar um ateu ipso facto como imoral, pois isso implicaria um ato judicativo sustentado no não reconhecimento do imperativo categórico como o fundamento único e suficiente da moralidade, afinal o não reconhecimento da moralidade é uma imoralidade e a 
expressão disso num ato judicativo público é um ato imoral. É exatamente isso que Kant parece entender quando no excerto da Vorlesungen, citado no início desse artigo, critica o “espírito de perseguição".

De uma perspectiva prático moral, uma crença religiosa poderia tentar se tornar moralmente obrigatória ao supostamente passar no teste de universalizabilidade estabelecido pelo imperativo categórico. Contudo, a obrigação de acreditar numa crença não passa no teste estabelecido pelo imperativo categórico. Naturalmente que um indivíduo pode desejar que sua crença religiosa se torne universal, no sentido de ser professada por todas as pessoas, mas não pode querer que sua crença seja universalizada. Isso fica mais claro quando se tem em mente que a vontade é a razão prática e, por conseguinte, "querer" é sempre um "querer de um sujeito racional". Um ser racional não pode querer que o objeto de uma crença seja transformado no objeto de um querer universal, pois isso seria o mesmo que querer racionalmente algo que não é racional, ou seja, haveria uma contradição na vontade racional. Isso pode ser explicado da seguinte forma: querer que algo que não pode ser objetivamente comprovado, seja teórica ou moralmente, torne-se obrigante para todo ser racional significa aceitar simultaneamente que qualquer outro ser racional possa impor a mim algo que ele próprio não possui fundamento racional suficiente para considerar conhecimento teórico ou prático. Ora, um ser racional não pode querer que seres racionais imponham-se mutuamente objetos de crenças que eles próprios racionalmente não podem considerar como objetivo, pois isso implicaria numa situação irracional em que seriam mutuamente impostas crenças contraditórias, o que destruiria finalmente a própria razão prática. Afinal, com certeza poderia haver um ser racional qualquer que assumiria como objeto do seu "querer" (sendo na verdade apenas um desejar) uma crença na irracionalidade ou uma crença que impedisse o próprio entendimento na busca pela verdade. Além de não fazer sentido falar da universalizabilidade ou da necessidade prática dos objetos da crença, também não faz sentido sustentar que a moral possa legislar sobre algo que não pode ser controlado pela própria vontade. Em outras palavras, da mesma forma que acontece com o amor patológico (cf. GMS, AA 04: 399) também a crença envolve uma determinada disposição que não pode ser ordenada. Kant deixa isso claro ao afirmar que se

a vontade tivesse uma influência imediata sobre a nossa convicção quanto àquilo que desejamos, estaríamos o tempo todo a construir quimeras de um estado de felicidade, e também não cessaríamos de tomá-las por verdadeiras. A vontade, porém, não pode lutar contra provas convincentes de verdades que contrariem seus desejos e inclinações. ( $\log$, AA 09: 74)

Portanto, qualquer crença religiosa não possui coercitividade ética, seja por que falha ao ethic@- Florianópolis, Santa Catarina, Brasil, v.14, n.2, p.222 - 251, Dez. 2015. 
tentar passar no teste de universalizabilidade estabelecido pelo imperativo categórico, seja por que o ato da crença fica fora do campo de atuação da própria vontade.

A não-coercitividade prática da crença religiosa também sé ocorre na perspectiva do direito. A crença religiosa sempre se sustenta e envolve um conceito de bem que não pode ser universalizado pelo imperativo categórico do direito e, por conseguinte, não tem legitimidade para ser institucionalizado juridicamente. A lei universal do direito é "age exteriormente de tal modo que o uso livre do teu arbítrio possa coexistir com a liberdade de cada um segundo uma lei universal" (MS, AA 06: 231). Toda crença religiosa envolve um conceito de perfeição, o qual, por sua vez, imbrica em um conceito de felicidade e de bem. Para Kant, o fundamento do direito somente pode ser a liberdade e não um conceito de bem. Logo,

[n]inguém pode me constranger a ser feliz à sua maneira (como ele concebe o bemestar dos outros homens), mas a cada um é permitido buscar a sua felicidade pela via que lhe parecer boa, contanto que não cause danos à liberdade dos outros (isto é, ao direito de outrem) aspirarem a um fim semelhante, e que pode coexistir com a liberdade de cada um, segundo uma lei universal. (TP, AA 08: 290)

Nesse sentido, qualquer Estado que deixasse que crenças religiosas determinassem o conteúdo da lei, estaria se tornando um Estado paternalista o qual trataria os súditos "como crianças menores que ainda não podem distinguir o que lhes é verdadeiramente útil ou prejudicial”, sendo tal governo "o maior despotismo que se pode pensar". (TP, AA 08: 291) Portanto, as leis de um Estado republicano, isto é, do único estado verdadeiramente legítimo jamais poderiam ser pensadas e estabelecidas tendo por base qualquer conceito de perfeição que fosse apregoado por alguma crença religiosa.

Além disso, de forma semelhante à perspectiva ética, também não cabe ao direito estabelecer um dever de crença. Isso se segue do seguinte: ao direito se vincula essencialmente a possibilidade de coerção a partir de fundamentos patológicos de ação, pois o direito não precisa assumir a lei moral como o próprio móbil da ação. Por isso, “os deveres recorrentes da legislação jurídica só podem ser deveres externos, porque esta legislação não exige que a ideia de dever, que é interna, seja por si mesma fundamento de determinação do arbítrio do agente" (MS, AA 06, 219). Como consequência, segue-se que "eu posso, decerto, ser obrigado por outros a praticar ações que estão, como meios, dirigidas para um fim, mas nunca ser obrigado a propor-me um fim, sendo que, pelo contrário, só eu posso fazer de algo um fim", ou seja, a Ética enquanto doutrina dos fins, contém deveres para os quais não podemos ser coagidos, enquanto que o Direito, enquanto doutrina de deveres para os quais é possível impor coação externa, não envolve fins, "porque uma coerção a tal dirigida (a ter 
fins) é uma contradição em si mesma." (MS, AA 06, 381) Ora, assumir uma crença religiosa envolve exatamente a mesma relação que a de se colocar um fim. Nesse sentido, o direito pode obrigar que os indivíduos finjam que acreditam em determinadas crenças religiosas por meio da coação para a realização de determinadas ações associadas com determinada crença religiosa, mas o direito não pode obrigar os indivíduos a assumirem verdadeiramente para si mesmos tal crença religiosa. Portanto, caso o direito estabeleça uma obrigação de fé, então ele assume algo que não lhe é legítimo e que, além disso, torna os indivíduos falsos e dissimulados e a própria crença algo odioso.

Assim, a conclusão dessa seção é a de que todos os assuntos de crença são teórica e moralmente incapazes de exercer legitimamente qualquer tipo de coação. É exatamente essa a avaliação que Kant expressa com relação, por exemplo, ao cristianismo, a saber, que caso se acrescente ao cristianismo

alguma autoridade (mesmo se fosse a divina), por mais bem intencionado que seja o propósito dela e ainda que seja realmente bom o seu fim, esvanece-se assim no entanto a sua amabilidade, pois ordenar a alguém que não só faça alguma coisa, mas que também que a faça de bom grado, é uma contradição. (EaD, AA 08, 338)

\section{Religião e veracidade}

Para apresentar e explicar a tese de que a liberdade de religião exige veracidade é preciso analisar aqui o texto de Kant Sobre o fracasso de todo empreendimento filosófico na teodiceia. Nesse texto, os argumentos apresentados na seção anterior são reconstruídos a partir da representação de um tribunal, onde tanto aqueles que se propõe provar, quanto aqueles que se propõe refutar uma teodiceia são confrontados no tribunal da razão pela própria razão. A conclusão de Kant é a de que em relação à teodiceia, não se pode nem provar nem refutar de maneira absoluta a sua possibilidade, mas para o ser humano ela somente pode ser um objeto de crença que, embora fraca, pode encontrar apoio na moralidade, de modo que se possa falar não de uma religião de súplica, mas de uma religião da boa conduta.

Após algumas páginas expondo argumentos sobre o fracasso de todo empreendimento filosófico na justificação teórica de uma teodiceia, ${ }^{5}$ Kant encerra o texto com algumas considerações bastante relevantes acerca da mentira e da veracidade, as quais se aplicam diretamente ao tema da religião. Ele inicia oferecendo uma definição de mentira:

Nem sempre se pode sustentar que aquilo que alguém diz para si mesmo ou para outrem é verdadeiro (pois se pode errar); mas em relação ao que se diz pode-se e deve-se sustentar que sua declaração ou confissão seja veraz, afinal somos imediatamente conscientes disso. No primeiro caso [da verdade], compara-se uma asserção com um objeto em um juízo lógico (através do entendimento); no segundo 
caso [da veracidade], no entanto, confessa-se o seu assentimento, isto é, compara-se uma asserção com o sujeito (frente a sua consciência). Ao se fazer uma declaração na primeira perspectiva sem se estar consciente da segunda, então se mente, pois se apresenta algo do qual não se estava consciente. ( $M p V T, 08: 267$, tradução própria)

Na sequencia Kant fala ainda de dois tipos de veracidade, uma formal e outra material. A veracidade material se refere à precaução de não se arriscar a cometer uma injustiça ou uma incorretude, enquanto que a veracidade formal se refere à consciência de ter tomado tal precaução em um determinado caso concreto. Kant continua:

Os moralistas falam de uma consciência equívoca, mas uma consciência equívoca é
um absurdo. Se houvesse tal coisa, então jamais se poderia estar certo de ter agido
de modo correto, pois até mesmo o juiz em última instância poderia errar. Na
verdade eu posso me equivocar no juízo, no qual eu acredito ter razão, pois isso
pertence ao entendimento que por si julga objetivamente (o verdadeiro ou o falso).
Todavia, na consciência, isto é, se eu de fato acredito ter razão (ou pretenda ter),
nisso eu não posso de modo algum errar, pois esse juízo ou, mais precisamente, esse
princípio diz apenas que eu assim julguei o objeto. ( $M p V T, 08: 268$, tradução
própria).

De certo modo pode-se simplificar essa caracterização kantiana dizendo que há uma distinção fundamental entre proferir um juízo falso e proferir uma mentira. A verdade e a falsidade são características lógicas de um juízo, enquanto que a veracidade e a mentira se referem a uma determinada atitude que o sujeito assume no momento em que profere o juízo seja para si mesmo, seja para outrem. A partir disso, a tese de Kant também afirma que é absolutamente impossível que alguém diga uma falsidade sem estar consciente dela. Em outras palavras, alguém pode proferir inconscientemente um juízo falso, isto é, pode proferir um juízo falso pensando que ele seja verdadeiro, mas é impossível que alguém diga uma mentira sem saber que a está dizendo. A mentira e a veracidade são, dessa forma, atributos da postura do agente com relação aos seus juízos, os quais representam sempre uma postura consciente qua ações de um agente livre. Ou a mentira e a veracidade são ações de sujeitos conscientes e livres ou não se pode falar mais de agentes livres ou de qualquer tipo de responsabilidade. Nesse caso, alguém que "mente" para si mesmo pode com o passar do tempo fortalecer esse hábito a partir de algum benefício que obtém das consequências uteis dessa atitude, mas jamais a mentira pode se transformar para ele em veracidade, ou seja, jamais se torna realmente uma mentira. Se isso acontecesse não se estaria mais falando de um sujeito livre, mas de um sujeito esquizofrênico que precisa ser tratado com medicação, pois nesse caso ele nem deve saber mais quem ele de fato é.

É importante trazer aqui mais uma passagem do texto kantiano: 
A consciência formal, a qual é o fundamento da veracidade, encontra-se no cuidado de se tornar consciente dessa crença (ou descrença) e não proferir nenhum assentimento do qual não se esteja consciente. Aquele que diz para si mesmo (ou o que é o mesmo em uma confissão religiosa frente a Deus) "eu acredito" sem talvez ter dado ao menos uma olhada em si mesmo para de fato saber se esta consciente desse assentimento ou também em que grau: ele mente não apenas uma mentira absurda (frente ao leitor de corações), mas uma mentira horrenda, pois ele mina o fundamento de todo intento virtuoso, a sinceridade. (MpVT, 08:268, tradução própria)

Nesse excerto, Kant aponta para duas consequências bastante impactantes, uma que fica bastante explícita e outra que permanece implícita e se tornará mais evidente com os exemplos da sequencia do texto. $A$ consequência explícita se refere à absurdidade de alguém dizer que acredita em Deus ou em dogmas ou pressupostos de uma determinada religião histórica sem ter feito uma inquirição em sua consciência para saber se de fato aplicou cuidadosamente o critério da veracidade formal. $A$ consequência implícita se refere à mentira de querer considerar uma crença um conhecimento, ou seja, o não reconhecimento de que a crença é distinta do conhecimento teórico e prático é também uma mentira, pois faz parte da veracidade reconhecer que a crença é um determinado tipo de assentimento que se distingue em espécie e também em grau de outros assentimentos.

Por maiores e mais impactantes que sejam as ações externas realizadas por um agente, elas não substituem para si mesmo ou para Deus (qualquer que seja o conceito que se tenha dele) essa inquirição na consciência. Kant está pensando aqui, por exemplo, nos casos em que religiões históricas exigem provas da crença de seus fiéis, ou mesmo no suposto caso do próprio Deus exigir tal prova. Nesse sentido, cabe trazer aqui a forma como Kant interpreta algumas narrativas bíblicas. No caso particular da narrativa bíblica relativa ao debate de Jó com seus amigos, Kant afirma o seguinte:

[é] de pouca importância os argumentos que ambas as partes apresentam em seus sutis e suprasutis raciocínios; mas o caráter no qual eles os apresentam merece a maior atenção. Jó fala como pensa e com uma coragem que qualquer um por si mesmo também poderia ter. Seus amigos, ao contrário, falam como se estivessem sendo secretamente ouvidos e julgados por aquele que é o mais poderoso e através de seus juízos tentassem conquistar sua graça mais pelo coração do que pela verdade. Essa malícia de seus amigos de alegar uma impostura sobre algo que precisam reconhecer ausência de compreensão e fingir uma convicção que de fato não possuem vai de encontro com a franqueza de Jó, a qual lhe é muito mais vantajosa à medida que se distancia da falsa bajulação que beira a imprudência. Jó afirma 'vocês querem defender Deus com algo que não é legítimo? Vocês querem compreender a sua pessoa? Vocês querem representar Deus? Ele os punirá quando secretamente contemplar as suas pessoas! Ele não aceita hipócritas perante si. (MpVT, 08:265f., tradução própria).

Segundo Kant, a conclusão que se pode tirar dessa narrativa bíblica é a seguinte: 
Jó tem consciência de não haver nada abusivo em seu discurso, senão que apenas se recusou a falar incautamente sobre coisas que lhe são demasiado altas e das quais nada compreende. Deus expressa sua condenação em relação aos amigos de Jó, pois eles não se pronunciaram tão bem a respeito de Deus (segundo a integridade) quanto seu servo Jó. Observando-se, assim, a teoria que ambas as partes sustentaram, então parece que os amigos de Jó se atribuem maior razão especulativa e devota humildade, enquanto que Jó provavelmente experimentaria um triste destino frente a qualquer julgamento de teólogos dogmáticos, frente a um Sínodo, uma Inquisição, uma congregação venerável ou qualquer alto consistório de nosso tempo. Portanto, não um entendimento privilegiado (Einsicht), mas apenas a veracidade do coração, a honestidade de não dissimular as suas dúvidas e a aversão em simular convicção quando não se a sente, especialmente frente a Deus (para quem esta artimanha é um absurdo): na pessoa de Jó são estas as características que, no veredito divino, dão preferência ao homem honesto em relação ao bajulador religioso. (MpVT, 08:266f., tradução própria).

Ora, nestas passagens pode-se perceber que a religião, qua religião que possa ser racionalmente aceita, precisa sempre reconhecer imediatamente que suas considerações a cerca de Deus e da sua intenção não são algo que possa ser conhecido. Quem se arroga o estatuto de representar os interesses de Deus não apenas está se equivocado, mas mente para si mesmo e para Deus, por conseguinte, comete um ato imoral.

De maneira semelhante pode ser compreendido a forma como Kant avalia a narrativa bíblica de Abraão. Segundo Kant,

Se Deus falar realmente ao homem este nunca consegue saber se é Deus que lhe fala. É absolutamente impossível que, por meio dos sentidos, o homem tenha de apreender o infinito, distingui-lo dos seres sensíveis e reconhecê-lo em qualquer coisa. - Mas, em alguns casos, pode muito bem convencer-se de que não pode ser Deus aquilo cuja voz ele julga ouvir; pois se o que nestes casos lhe é proposto for contrário à lei moral, então, por majestoso que se lhe afigure o fenômeno e ultrapassando até toda a natureza, deve tê-lo por ilusão*. [*] Pode servir de exemplo o mito do sacrifício que Abraão quis fazer, por ordem divina, mediante a imolação e a cremação do seu único filho (a pobre criança teve ainda, sem saber, de transportar a lenha). A esta pretensa voz divina Abraão deveria responder 'É de todo certo que não devo matar o meu bom filho; mas não estou seguro de que tu, que me apareces, seja Deus, e que tal te possas tornar, mesmo se esta voz ressoasse a partir do céu (visível).'( $S F$, AA 07: 63n.) ${ }^{6}$

Por mais majestoso que possa aparecer um fenômeno, mesmo assim, deve-se ter a sinceridade de confessar que isso por si mesmo não pode estabelecer e fundar uma crença inabalável e absoluta, pois contraria os princípios teóricos e práticos da razão. Nossa razão possui princípios que se fazem ouvir, mesmo para aqueles que não querem, ou seja, mesmo alguém como Abraão, que supostamente tivesse presenciando um fenômeno de uma voz vinda dos céus que lhe tenha ordenado imolar e cremar seu filho, sabia que tal não poderia ser ordenado por Deus e, por isso, Kant afirma que ele deveria ter dito, 'Deus não ordenaria tal coisa'. Para que alguém pudesse verdadeiramente acreditar que Deus tivesse ordenado tal coisa, deveria aplicar o princípio da veracidade formal em tal situação, o que para Kant, 
tornaria impossível que se acreditasse que Deus estaria solicitando tal atitude. Por que seria impossível? Pois o âmbito da crença possui uma independência com relação ao domínio teórico e prático da razão pura, isto é, a crença não pode ser derivada de nenhum conhecimento teórico ou prático, mas isso não significa que ela seja completamente autônoma e que possa se estabelecer a partir de princípios que contradigam os princípios da razão pura, seja no seu uso teórico ou prático. Para Kant o reconhecimento desse aspecto não é um privilégio do filósofo, pois ainda que de modo grosseiro, ele já está presente no julgamento de todo juízo comum.

A veracidade no reconhecimento de que a crença religiosa não constitui um conhecimento teórico nem prático é algo que em nada tem a ver com a importância que essa crença tem para a vida do indivíduo. Para um determinado sujeito, sua crença religiosa pode ser psicológica e socialmente tão importante quanto os conhecimentos de matemática ou de moralidade, mas ele deve saber e, por isso também sabe que a sua crença não obriga ninguém, nem a ele, nem a qualquer outro, o que é exatamente aquilo que, por sua vez, o conhecimento teórico e prático fazem. Em outras palavras, para Kant todo o sujeito tem consciência, ainda que muitas vezes inconfessa, que uma crença sua, por mais invariável e firme que ela seja, possui uma natureza distinta do saber, ou seja, ela é de uma natureza tal que não aceita qualquer tipo de obrigação. ${ }^{7}$

Ora, é exatamente por que sempre é possível aplicar o critério formal e material da veracidade que qualquer um pode saber que os objetos de crença são distintos dos objetos de conhecimento teórico e prático. Assim, qualquer indivíduo pode ter a consciência não simplesmente do erro, mas da imoralidade de todo tipo de perseguição religiosa ou mesmo de se lançar ódio religioso sobre outrem. Para Kant, portanto, faz parte da sinceridade de qualquer indivíduo e, por conseguinte, de qualquer instituição religiosa reconhecer a falta de certeza teórica e prática sobre a realidade do objeto de crença religiosa, ou seja, faz parte da sinceridade reconhecer que não se sabe dessas coisas.

Ao se relacionar essa conclusão com a política e o direito, pode-se dizer que o Estado, para Kant, não pode pactuar com qualquer tipo de perseguição religiosa, envolvendo ela violência física ou não. A própria legitimidade do Estado se assenta em seu fundamento moral o qual, por conseguinte, pode não apenas impedir a perseguição religiosa, o que estaria no âmbito da proteção da liberdade dos indivíduos, mas também pode fomentar meios para minar a imoralidade que se assenta na mentira a respeito de assuntos de religião. É nesse contexto que se passa agora a analisar a tese kantiana da importância da publicidade para o esclarecimento moral em assuntos de religião. 


\section{Religião e publicidade}

A relação que Kant estabelece entre a religião e a publicidade ocorre em três sentidos diferentes, a saber, a publicidade para se discutir a respeito de assuntos de religião; o ensino do exercício da publicidade sobre temas de religião e, finalmente, a incapacidade de máximas com conteúdos religiosos passarem pelo princípio político da publicidade, nomeado por Kant de princípio transcendental positivo do direito público.

Publicidade é a condição pela qual algo pode ser publicamente dito, ou seja, se refere à capacidade de se manifestar em público em voz alta (seja por palavras faladas ou escritas). A publicidade se opõe ao cerceamento da liberdade de fala, ao sigilo forçado jurídica ou socialmente a respeito de opiniões, crenças e pensamentos. A publicidade no sentido de assuntos de religião se refere, nesse caso, ao direito à liberdade de se fazer um uso público da razão em assuntos de religião. No ensaio Resposta à pergunta: que significa esclarecimento? Kant acentua prioritariamente o esclarecimento nas coisas de religião, pois, segundo ele, a tutela religiosa além de ser "a mais prejudicial, é também a mais desonrosa" ( $W A$, AA 08: 41). ${ }^{8}$ Quando um Clérigo diz: "não raciocines, acredita!", abre-se espaço para a completa heteronomia da razão prática, a qual transforma os seres humanos em simples meios, em animais que, assim como os bois de canga, são incapazes de decidirem algo por conta própria, se tornam incapazes de pensar, incapazes de serem livres e, finalmente, incapazes de serem morais. Quando um Clérigo diz "não raciocines, acredita" ele está sendo imoral, um algoz da veracidade e da sinceridade, as quais são o fundamento de toda a moralidade. Ele quer se colocar como representante de Deus e atribui a si, de forma arrogante e mentirosa, o papel de seu intérprete. Quando as leis de um Estado reforçam juridicamente essa postura imoral do Clérigo, então tal Estado mina a sua própria legitimidade, pois ele não pode transformar em lei algo que o povo por si mesmo não pode decidir em relação a si próprio. Nas palavras de Kant,

\footnotetext{
é absolutamente proibido coadunar-se numa constituição religiosa pertinaz, por ninguém posta publicamente em dúvida, mesmo que só durante o tempo de vida de um homem e deste modo aniquilar, por assim dizer, um período de tempo no progresso da humanidade para melhor e torná-lo infecundo e prejudicial para a posteridade. Sem dúvida, um homem, para a sua pessoa, e mesmo então só por algum tempo, pode, no que lhe incumbe saber, adiar a ilustração; mas renunciar a ela, quer seja para si, quer ainda mais para a descendência, significa lesar e calcar aos pés o sagrado direito da humanidade. Mas o que não é lícito a um povo decidir em relação a si mesmo menos o pode ainda um monarca decidir sobre o povo, pois a sua autoridade legislativa assenta precisamente no fato de na sua vontade unificar a vontade conjunta do povo. (WA, AA 08: 39)
} 
Dessa forma, para Kant, a publicidade em assuntos de religião significa que os temas de religião devem ser trazidos para o espaço público respeitando-se os princípios da liberdade do uso público da razão, ou seja, a liberdade de se discutir assuntos de religião deve possuir, de um lado, um espaço específico e, de outro, deve ser realizado de um determinado modo. Por exemplo, um padre não teria o direito de interpretar a Bíblia como lhe parecer melhor no momento em que ele estiver rezando uma missa, pois nesse momento ele está fazendo um uso privado da sua razão, ou seja, ele é um funcionário de uma determinada instituição. Da mesma forma, um indivíduo qualquer não tem o direito de invadir uma missa e questionar os ensinamentos do padre no meio do seu sermão. Contudo, a liberdade do uso público da razão assegura que o padre possa colocar suas dúvidas e sugerir novas interpretações do texto bíblico quando ele estiver em uma reunião de padres ou quando o ele esteja em um espaço público onde seja possível ocorrer um debate. Da mesma forma, qualquer indivíduo tem o direito de publicar livros, jornais, notícias ou panfletos que questionam certa interpretação da Bíblia pregada na missa ou mesmo o próprio fundamento ou o sentido da crença religiosa. Além disso, o uso público da razão também exige um determinado modo de ser conduzido, isto é, ele deve ser feito de modo tal como um erudito o faria, ou seja, deve se assentar em argumentos racionais e não em sofismas ou subterfúgios que apelam ao medo ou a preconceitos injustificados. $^{9}$

O segundo sentido em que a publicidade pode se referir a assuntos de religião é quando o Estado, enquanto um Estado republicano, toma medidas para garantir e promover essa publicidade. No excerto da Vorlesung über Moralphilosophie anotada segundo Collings citado no início deste artigo, Kant afirma que em "questões de verdade de religião não se pode utilizar nenhuma forma de violência, mas razões. A verdade se defende por si mesma e um erro se prolonga por mais tempo se contra ele for usado violência. A liberdade de investigação é o melhor instrumento da verdade.” (V.MoCollings, AA 27, 453ff. Tradução própria) A posição de que a verdade prevalecerá depende intrinsecamente da garantia da possibilidade da liberdade de investigação. Mas essa liberdade de investigação que culmina na liberdade do uso público da razão, mencionado acima, depende, por sua vez, de uma liberdade que seja garantida e promovida em dois âmbitos, a saber, primeiro, a liberdade dos acadêmicos em investigar e debater os assuntos de religião; segundo, o ensino organizado e mantido por parte do Estado dos princípios da publicidade para as crianças.

O primeiro âmbito se refere à garantia de um conflito legal das faculdades no âmbito da Universidade. O conflito ilegal 
é uma disputa pública das opiniões, por conseguinte, um conflito erudito ou quanto à substância, se não fosse sequer permitido impugnar uma proposição pública, porque não é permitido proferir um juízo público sobre ela e o seu contrário; ou simplesmente quanto à forma, se o modo como é conduzida a discussão não se assenta em argumentos objetivos do adversário, mas em motivos subjetivos que determinam o seu juízo mediante a inclinação para, graças à astúcia (que engloba igualmente a corrupção) ou à violência (ameaça), o levar ao consentimento. ( $S F, \mathrm{AA}$ 07: 29)

Nessa definição que envolve um aspecto substancial e outro formal fica evidente que há diversas formas de se impedir um conflito legal das faculdades. No aspecto substancial de um conflito ilegal está em questão a própria possibilidade de liberdade de expressão e, por conseguinte de liberdade de pensamento, visto que, como apontou Kant outrora, a restrição civil da liberdade de falar e escrever repercute diretamente na própria capacidade de pensar. ${ }^{10}$ No conflito ilegal das faculdades ocorre a constante derrota da Faculdade de Filosofia. É nesse sentido que um conflito legal das faculdades deve ocorrer dentro da Universidade, sem apelar para os preconceitos do governo ou do povo, o qual não pode funcionar como tribunal da ciência. ${ }^{11}$ Kant acredita que ao se respeitar a legalidade do conflito entre as faculdades, então a Filosofia pode colocar questionamentos à Teologia, mas principalmente, pode mostrar-lhe que a única forma dela fazer um uso coerente, seja da sua doutrina histórica, seja de suas ideias religiosas é quando adota como pedra de toque da verdade da sua interpretação da fé histórica uma crítica da razão pura e os conceitos morais da razão prática pura. Isso significa que as religiões históricas devem perceber que todo antropomorfismo que não seja simbólico tem consequências extremamente prejudiciais (Cf. $R G V$, AA 06: 64n) e que, se a razão prática pura não oferecesse os arquétipos morais pelos quais a própria religião histórica devesse se guiar, a última seria destituída de todo sentido (Cf. RGV, AA 06: 104. 19-26).

O Estado pode velar pelo esclarecimento moral de "forma negativa" dentro das seitas eclesiais (igreja visível) na medida em que promove o conflito legal das faculdades e exige uma boa formação religiosa estatutária aos clérigos. O clérigo, assim como qualquer outra profissão pode e deve ser regulada pelo Estado, isto é, o Estado tem o direito de exigir uma boa formação daqueles que servirão nos templos. Essa formação deve ser dupla: por um lado, ela deve dizer respeito ao conhecimento adequado dos fundamentos históricos de determinada seita eclesial (conhecimentos profundos de exegese bíblica, por exemplo); por outro, deve ter um conhecimento adequado dos princípios morais que sustentam o Estado e dos princípios morais da verdadeira religião. Nesse sentido, Kant sugere que a formação de todos os sacerdotes, de qualquer religião aceita pelo Estado em seus domínios deva possuir um estudo da doutrina filosófica da religião. ${ }^{12}$ Assim, o Estado não interfere diretamente na ortodoxia 
das religiões históricas, mas indiretamente na medida em que vela pela formação moral dos clérigos, garantido que as seitas eclesiais que ele permite em seu domínio não contradigam, em primeiro lugar, os fins do próprio Estado e, em segundo lugar, garantindo que elas tenham condições de ajudar na formação moral dos cidadãos. É importante frisar que não se trata aqui de uma interferência direta da política do Estado nos assuntos da religião histórica, mas de uma garantia de que ocorra o tão frutífero conflito legal das faculdades, afinal, como poderia haver um conflito legal das faculdades se uma faculdade se negasse a participar do debate? Ou seja, como seria possível haver o conflito legal das faculdades, se uma determinada faculdade se retirasse da Universidade e constituísse um domínio próprio? Tal postura seria uma postura de um sectarismo erudito, o que não pode ser aceito em um Estado republicano, pois isso poderia colocar em cheque o seu próprio fundamento. Em outras palavras, o Estado não diz o que as seitas históricas têm de pregar, mas isso não significa que ele não possa exigir duas condições, primeira, que o culto das seitas eclesiais não contradiga os fins essenciais do próprio Estado (a manutenção da igual liberdade) e, segunda, que a formação dos clérigos, enquanto eruditos, não seja deficiente e sectária. O clérigo, enquanto erudito, “tem a plena liberdade e até a missão de participar ao público todos os seus pensamentos cuidadosamente examinados e bem-intencionados sobre o que de errôneo há [no símbolo da Igreja], e as propostas para uma melhor regulamentação das matérias que respeitam à religião e à Igreja." (WA, AA 08: 38) Contudo, não é o Estado que oferece os princípios para a formação erudita, mas a Universidade, que para Kant, deve ser uma instituição autônoma dentro do Estado, a qual é formada pela comunidade de eruditos organizada de modo republicano. Mas o que a Filosofia ensinaria aos estudantes de Teologia? Ensinaria, por exemplo, que toda a interpretação da Bíblia, ou de qualquer outro livro ou ensinamento considerado sagrado deve ser pautado por uma interpretação simbólica a partir de conceitos morais, ou seja, que se trata, sobretudo, de apresentar a lei moral a partir de uma perspectiva religiosa, ou ainda e igualmente importante, que toda a crença religiosa não pode envolver qualquer tipo de coercitividade, tal como apresentado na primeira seção deste artigo.

Além disso, o ensino da publicidade e de seus princípios também deve ser ensinado para as crianças na escola, pois senão, ainda que o governo do Estado velasse pelo conflito legal das faculdades, o povo, ignorante e muitas vezes corrompido pela atuação dos clérigos que gostariam de mantê-lo na menoridade, poderia por meio de uma eventual modificação das leis do próprio Estado colocar em risco o conflito legal das faculdades. Mais do que isso, a falta de esclarecimento em assuntos de religião pode fazer com que surjam no âmbito social diversas formas de perseguição religiosa, ainda que não físicas, mas ainda assim moral e 
socialmente violentas. Isso não pode ser permitido em um Estado republicano, o qual precisa tomar providências para que isso não ocorra ou mesmo para que uma tendência religiosa sectária não se espalhe e contamine a sociedade civil. Kant sugere tal leitura na seguinte passagem:

É fácil prever quão rapidamente essa confissão externa e cega, a qual facilmente se pode associar com uma confissão interna igualmente inverídica à medida que se constitui em um meio de ganho, pode produzir gradualmente uma determinada falsidade no próprio modo de pensar de um ser comum. Uma purificação pública desse modo de pensar permanecerá provavelmente por longo tempo suspensa, até que talvez algum dia ela possa se realizar sob a proteção do livre pensamento de um princípio universal de ensino e educação. ( $M p V T, 08: 269$, tradução própria)

Essa confissão interna e externamente cega e inverídica, a qual Kant se refere está vinculada ao tópico trabalhado na seção anterior, a saber, a veracidade. Nesse caso, a falsidade que está presente em várias religiões históricas, quando elas não reconhecem publicamente que sua crença é apenas uma crença que não envolve nem certeza teórica, nem certeza prática e é fomentada por um meio do ganho financeiro ou de poder. Uma purificação pública dessa hipocrisia só poderá acontecer quando o Estado proteger publicamente o livre pensamento, ou seja, quando o Estado permitir por lei o livre conflito legal das faculdades, mas também toda a liberdade do uso público da razão no sentido de que qualquer um possa fazer enquanto erudito. Mas isso depende, por sua vez, de que a garantia dessa publicidade, a garantia do livre pensamento, seja transformado em um princípio universal de ensino e educação. Em outras palavras, o Estado somente conseguirá proteger o contínuo esclarecimento de seus cidadãos se ele assumir como tarefa sua o ensino público do princípio da publicidade e o significado e as condições de se fazer um uso público da sua razão. Em outras palavras, a garantia da publicidade e da liberdade de se fazer um uso público da razão em assuntos de religião depende do fato de que seja ensinado nas escolas o significado da crença, especificamente a respeito do fato dela não poder comportar nenhum tipo de coercitividade teórica ou prática.

Finalmente, o terceiro aspecto da publicidade relativa a questões de religião se refere à impossibilidade de qualquer princípio com conteúdo religioso passar pelo teste do princípio político-jurídico da publicidade entendido como princípio transcendental do direito público. Segundo Kant,

Toda a pretensão jurídica deve possuir a possibilidade de ser publicada e a publicidade pode, pois, já que é muito fácil julgar se ela ocorre num caso concreto, isto é, se a publicidade se pode harmonizar com os princípios do agente, subministrar a priori na razão um critério oportuno e de fácil utilização, para 
conhecer imediatamente no último caso, por assim dizer, mediante um experimento da razão pura, a falsidade (ilegalidade) da pretensão suposta (praetensio juris). (ZeF, AA 08: 381)

A possibilidade da publicidade é então um critério político-moral para saber se uma determinada pretensão pode ser considerada como injusta. Tem-se assim o princípio que serve de teste para averiguar a falta da consonância de uma determinada máxima política com relação à moral, a saber, "são injustas todas as ações que se referem ao direito de outros homens, cujas máximas não se harmonizem com a publicidade” (ZeF, AA 08: 381). Tal princípio serve como teste para saber se determinada máxima pode ou não ser consoante com a moral. Nesse caso, por exemplo, se um determinado grupo religioso no contexto de um país com pluralismo religioso estabelece um plano para modificar as leis do país ou mesmo a política do governo de acordo com os seus princípios religiosos, ou mesmo para ter benefícios políticos ou financeiros, então segundo Kant, é fácil perceber que se tal grupo enunciasse em voz alta sua máxima, os demais grupos religiosos se articulariam para frustrar tal empresa. Em outras palavras, tal procedimento só consegue alcançar seu fim se ele for executado em sigilo ou dissimuladamente, portanto, não se harmonizariam com o princípio da publicidade.

Contudo, o fato de algumas máximas não serem impossibilitadas ao se tornarem públicas, isso não as torna em si mesmas morais e justas. A formulação do princípio da publicidade acima indicado apresenta apenas um critério negativo, isto é, serve para indicar quando falta a consonância com a publicidade para uma máxima. Mas pode ocorrer que determinado grupo religioso já esteja ocupando ou influenciando quem tem o poder de decisão, ou possua poder político ou financeiro suficiente para não temer que, ao publicizar sua máxima, ela seja frustrada. Em outras palavras, com o princípio da incompatibilidade das máximas do direito com a publicidade, temos uma boa indicação da falta de consonância entre a política e a moral (como teoria do direito), mas disso não se pode concluir o inverso, isto é, "que as máximas que toleram a publicidade são por si mesmo justas, porque quem detém o supremo poder de decisão não precisa ocultar as suas máximas.” (ZeF, AA 08: 385) É por isso que Kant apresenta então o princípio positivo da publicidade, o qual averigua se a máxima é em si mesmo justa. Tal princípio positivo estabelece que: "todas as máximas que necessitam da publicidade (para não fracassarem no seu fim) concordam simultaneamente com o direito e a política." (ZeF, AA 08: 386) Neste princípio está pressuposto que somente um fim que se realiza por uma máxima que se torna pública pode ser considerado como justo, pois quando um fim "só mediante a publicidade, isto é, através da eliminação de toda a desconfiança quanto às máximas, se pode alcançar, então estas devem estar também em concordância com 
o direito público, pois só no direito é possível a união dos fins de todos.” (ZeF, AA 08: 386)

Ora, a partir disso pode-se concluir o seguinte: permitir que grupos religiosos estabeleçam suas demandas ou visões de mundo sustentadas em suas crenças no âmbito da política é uma falta moral grave que solapa os fundamentos de legitimidade do Estado e da atuação política das suas instituições. A partir das características da própria crença religiosa, tal com apontado na primeira seção deste artigo, segue-se que nenhuma demanda ou visão de mundo sustentada sobre alguma crença religiosa pode conseguir a adesão de todos os possíveis envolvidos. ${ }^{13}$ Apenas os princípios do direito podem alcançar essa adesão. Assim, por exemplo, todos podem concordar com o direito à liberdade de culto religioso, seja os indivíduos religiosos nas suas mais variadas seitas históricas, seja os indivíduos que não possuem crença religiosa alguma. Mas nem todos podem e irão concordar em atribuir uma liberdade de culto que assuma como seu objetivo impor a todos os demais a sua própria perspectiva religiosa. Desse modo, a liberdade de culto religioso possui um limite moral, um limite de direito, a saber, manter-se fora da esfera da política e sem contradizê-la em seus fins que podem ser aceitos por todos, enquanto seres dotados de razão prática.

A partir disso pode-se concluir que plataformas religiosas (oriundas de religiões históricas) não podem fazer parte da política, pois não satisfazem, pela própria natureza dos seus princípios e pressupostos, o critério central da política. Para que algo possa ser legitimamente aceito na esfera da política deve passar pela avaliação do princípio da publicidade (o qual faz referência direta a forma da universalidade também presente no imperativo categórico), a qual afirma que todos devem poder aceitar a máxima pela qual um determinado ato político é realizado e inclusive com ela estarem dispostos a colaborar. É difícil ou mesmo impossível acreditar que ateus ou mesmo indivíduos religiosos esclarecidos compactuem com a transformação de princípios de determinada religião histórica em leis ou políticas públicas em um Estado republicano. No caso brasileiro, isso significaria, por exemplo, a proibição de todo ou qualquer partido político que assumisse como sua identidade e em sua plataforma o cristianismo ou qualquer outra crença religiosa, ou ainda, a proibição de qualquer espaço religioso ser utilizado como espaço para campanha política. ${ }^{14}$ Esse segundo aspecto é decorrente do fato de que é da natureza de toda crença religiosa histórica se fundar sobre fatos e submeter a razão a eles, o que Kant nomeia de uma forma de misticismo. ${ }^{15}$ Nesse sentido, para a filosofia kantiana seria ilegítimo que durante um culto religioso ou na posição de "tutor religioso do povo", os clérigos se arrogassem o direito de orientar politicamente os seus fiéis. Claro que os clérigos e sacerdotes das religiões históricas 
podem participar da política, mas devem fazer isso em pé de igualdade a todos os outros cidadãos, isto é, eles podem participar da política enquanto qualquer outro cidadão e não enquanto "pastores de almas", ou seja, como indivíduos que se arrogam uma "autoridade mística" sobre os demais concidadãos. Esse é o caso, pois em um culto religioso não há espaço para se realizar um uso público da razão, logo, não é ali o espaço para a política, a qual exige sempre em si mesma a publicidade.

\section{Considerações finais: Liberdade e religião}

Para a filosofia kantiana, o fundamento de legitimidade que baliza todas as relações interpessoais, sejam éticas, jurídicas ou políticas, é a liberdade. Também as relações estabelecidas nos contextos que envolvem assuntos religiosos ou que a eles se referem direta ou indiretamente são por ela legitimadas e também restringidas. Por isso pode-se dizer que é a liberdade que permite a religião e não a religião que permite a liberdade. A liberdade tem precedência, tem mais valor e é o fundamento de toda legitimidade para as inter-relações humanas. Nesse caso, sempre que houver um choque entre liberdade e religião é a última que deve ceder lugar.

Tal como se mostrou neste artigo, a partir dos princípios da filosofia kantiana pode-se dizer que a religião não comporta nenhum tipo de coercitividade e quem disser ou defender o contrário está sendo imoral, um indivíduo mentiroso, falso, pois sabe que assuntos de religião são apenas objetos de crença e que não são e não podem ser comprovados como verdadeiros. Tais indivíduos hipócritas e mentirosos estariam apenas buscando com sua mentira poder, riqueza ou honras. Além disso, se torna uma questão de direito a legitimidade para qualquer um ter a liberdade de fazer um uso público da sua razão em assuntos de religião. Faz parte da liberdade e do seu direito inato, ter a liberdade de debater publicamente esses temas. Nesse caso, o Estado não deve apenas velar para que isso ocorra no espaço público e nas universidades, mas também deve promover o esclarecimento moral e religioso a partir do fomento do conflito legal das faculdades e do ensino público a respeito do significado e da importância do princípio da publicidade. Por fim, por mais que questões de religião sejam debatidas publicamente, conteúdos religiosos jamais poderão constituir eles próprios conteúdos de máximas legítimas para a atuação política, pois são incapazes de passar pelo princípio positivo da publicidade.

Nesse caso, a partir dessas conclusões pode-se apontar rapidamente aqui pelo menos para algumas consequências diretas aos problemas e experiências recentes. No caso do Brasil, não apenas o discurso e as crenças religiosas entram no campo do discurso político como 
também são aceitos como elementos que podem constituir uma plataforma política de um determinado partido. Um Estado republicano, o único legítimo para Kant, deveria simplesmente proibir tais plataformas religiosas e tais partidos e isso seria feito exatamente com base na legitimidade do direito à liberdade de religião.

Tome-se agora o caso do atentado ao jornal satírico Charlie Hebdo. A liberdade de expressar publicamente sua opinião sobre uma crença religiosa é algo que deve ser garantido a partir do próprio direito fundamental à liberdade. Assim, se, por um lado, atribui-se liberdade para os indivíduos professarem determinada crença religiosa, também deve ser permitido liberdade para outros indivíduos questionarem tal crença, do contrário se estaria aplicando de maneira unilateral e, portanto, equivocadamente o princípio da liberdade. Poderse-ia alegar que a liberdade de se imprimir charges consideradas ofensivas a uma determinada religião não se constitui em um uso público legítimo da razão, pois não se está comportando como um erudito que discorda respeitosamente de certas opiniões, mas se age como um caluniador que provoca uma real ofensa para todos os crentes daquela seita histórica. Talvez houvesse aqui um ponto, porém, se isso fosse levado às últimas consequências, então se deveria proibir praticamente todas as religiões históricas, pois em seus livros sagrados, seus cultos ou seus preceitos, elas também expressam inúmeros preconceitos e ofensas em relação aos pagãos, aos judeus, aos negros, às mulheres, aos escravos, aos homossexuais, ou aos não crentes em geral. Não há diferença alguma em relação a uma charge sobre o Papa ou sobre Maomé ou os diversos ensinamentos da ortodoxia dessas igrejas quando afirmam que os não crentes irão para o inferno. Ora, ou tudo entra no direito a liberdade, ou nada entra, pois um dos aspectos centrais do princípio da liberdade é que ele obriga igualmente a todos segundo uma lei universal. Como é altamente duvidoso que as religiões históricas queiram parar de se pronunciar direta ou indiretamente em relação àqueles que não fazem parte dos seus seguidores, então deve caber a todos o direito de se expressar publicamente a respeito do que pensam ou acham das diversas religiões ou mesmo do próprio ato de adotar uma religião em si.

Nesse contexto cabem ainda algumas breves considerações, para não estender em demasia este artigo. Existe uma diferença fundamental entre os seguintes juízos: "a religião judaica é uma bobagem" e "os judeus pertencem a uma raça inferior”; ou "o candomblé é uma insensatez" e "o candomblé é uma religião ilegítima"; ou "que Jesus seja o filho de Deus é uma estupidez" e "cristãos devem ser jogados aos leões"; ou "Deus criou o mundo" e "a narrativa bíblica da criação do mundo é verdadeira"; ou finalmente "os ateus vão arder no 
fogo do inferno" e "ateus são imorais e maus cidadãos". No caso do primeiro tipo de juízo, o que está em questão é uma crítica ou mesmo uma desconsideração completa a uma determinada crença religiosa que se assenta por sua vez em uma crença. Já no segundo caso, trata-se de juízos que podem ser comprovados como objetivamente equivocados, seja a partir de princípios teóricos ou práticos, por isso tais juízos ao serem formulados agridem tais princípios. Em outras palavras, é objetivamente falso, seja a partir de princípios teóricos ou práticos, que os judeus são uma raça inferior, que o candomblé é uma religião ilegítima, que os cristãos devem ser jogados aos leões, que a narrativa bíblica da criação do mundo está correta ou que os ateus são imorais e maus cidadãos. As afirmações do primeiro tipo são objetos de opinião e de crença, mas as afirmações do segundo tipo podem ser comprovadas como falsas a partir de princípios objetivos teóricos e práticos.

Mas qual a atitude que se deve tomar contra as facções religiosas que existem no interior da sociedade, mas que não aceitam os princípios morais do próprio Estado de direito ou agem ou proferem juízos do segundo tipo apresentado acima. Ora, para Kant não resta dúvida de que tais seitas religiosas devem ser suprimidas, ainda que para isso seja necessário usar força coercitiva, pois sua existência infringe o princípio fundamental do direito que é o respeito pela liberdade dos outros, e a supressão de uma coerção ilegítima inicial é em si mesma um ato de justiça. É justo, portanto, eliminar todas as religiões históricas que se mostram incapazes de conviver pacificamente e respeitando os princípios do Estado de direito. E qual seria a atitude com as seitas religiosas incapazes de conviver mutuamente com a liberdade religiosa, mas que se situam em outro país. Todo o Estado tem o direito à autodefesa e o rompimento com todas as relações políticas e comerciais com o Estado que abriga tal facção. Além disso, não é possível aceitar um Estado que dá abrigo a tais seitas numa Federação das Nações. 


\title{
Notas:
}

\begin{abstract}
${ }^{1}$ Todas as obras de Kant serão citadas segundo a Akademie Ausgabe. Por exemplo: “WA, AA 08: 38”, sendo "WA" a sigla que indica o nome da obra em alemão (nesse caso, ver a bibliografia para conferir as siglas), depois "AA 08" significando o volume oitavo da edição da academia, e, em seguida, o número da página. As letras "f" e "ff" Significam página(s) seguinte(s). A letra "n” significa "nota de rodapé".
\end{abstract}

2 Pode-se dizer que uma hipótese, de modo geral, constitui uma opinião dos cientistas, a qual não é especificamente, mas apenas metodologicamente distinta das opiniões em geral. Ela é metodologicamente diferente, pois está comprometida desde o princípio com a perspectiva de se produzir um experimento para que ela possa ser comprovada ou, ao menos, corroborada.

${ }^{3}$ Sobre a forma como Kant entende os princípios regulativos conferir $K r V$, B670-732 ou ainda a segunda parte da Crítica da faculdade do Juízo.

${ }^{4}$ Sobre isso conferir meu artigo publicado...

${ }^{5}$ Cf. "A teodiceia, como foi mostrado, tem a ver não tanto com uma tarefa com interesse para a ciência, mas muito mais com uma tarefa relacionada com coisas de fé." (MpVT, 08:267).

${ }^{6}$ A relação de Kant com o cristianismo pode ser tematizada a partir de vários aspectos. Porém, por mais envolto que ele estivesse com a tradição pietista e por mais que tivesse se manifesto como cristão, não acredito que essas considerações sejam suficientes para colocar em cheque sua filosofia da religião ou mesmo as suas considerações críticas sobre a religião em geral. A meu ver, um dos principais motivos teóricos que fez com que Kant valorasse positivamente o cristianismo (e não necessariamente as igrejas cristãs) foi o profundo caráter de igualdade e não coercitividade que estavam associados com os ensinamentos cristãos, ou seja, aspectos que encontram legitimidade no interior da filosofia kantiana. Nesse sentido, qualquer outra religião histórica que satisfizesse esses critérios, teria, segundo a filosofia kantiana e, acredito também que do próprio Kant, a mesma avaliação positiva.

${ }^{7}$ Mesmo que se trate de uma crença racional, a qual, segundo Kant, não é inferior a nenhum saber, ainda assim, é distinta com relação a sua natureza e também não pode obrigar prática nem teoricamente. Sobre a validade e a invariabilidade da crença racional ver WDO, AA 08: 141.

${ }^{8}$ Cf. "s]ob todos os meios de [(condução)] em que o povo pode ser pacientemente dominado pelo próprio homem, o mais vigoroso é a crença em poderes incertos, os quais são suprassensíveis e ocorreram apenas em favor de certos escolhidos". "Unter allen [(Leitungs)] Mitteln Menschen ja selbst Volker ge... und geduldig beherrscht werden können ist der Glaube an unsichtbare Mächte welche nur gewissen Auserwählten zu Theil geworden [ist] und übersinnlich sind die Kräftigste.” (Cf. KANT apud HENRICH, 1966).

${ }^{9}$ Sobre a minha interpretação a respeito do significado e da legitimidade da liberdade do uso público da razão e sua relação com o esclarecimento ver meu artigo...

${ }^{10} \mathrm{Cf}$. "A liberdade de pensar opõe-se em primeiro lugar a coação civil. Sem dúvida ouve-se dizer: a liberdade de falar ou de escrever pode nos ser tirada por um poder superior, mas não a liberdade de pensar. Mas quanto e com que correção poderíamos nós pensar, se por assim dizer não pensássemos em conjunto com outros, a quem comunicamos nossos pensamentos, enquanto eles comunicam a nós os deles! Portanto, podemos com razão dizer que este poder exterior que retira dos homens a liberdade de comunicar publicamente seus pensamentos roubalhes também a liberdade de pensar, o único tesouro que ainda nos resta apesar de todas as cargas civis, e graças ao qual unicamente pode ainda ser produzido um remédio contra todos os males desta situação" (WDO, AA 08: 144).

${ }^{11}$ Cf. "as doutrinas e as opiniões que as Faculdades [no caso, as Faculdades da Teologia, Direito e Medicina com relação à Faculdade da Filosofia] têm de resolver entre si em nome dos teóricos, disseminam-se num outro gênero de público, a saber, no de uma comunidade erudita que se ocupa das ciências; o povo resigna-se a nada de tal entender, mas o governo acha que não lhe convém lidar com ações eruditas.* [*] Pelo contrário, se o conflito fosse apresentado à comunidade civil (publicamente, por exemplo, nos púlpitos), como de bom grado tentam os profissionais (sob o nome de práticos), seria de modo incompetente submetido ao tribunal do povo (ao 
qual não cabe juízo algum em matéria de ciência) e deixa de ser um conflito de eruditos; e surge então o estado de conflito ilegal, que acima se mencionou, em que se expõe doutrinas conformes às tendências populares e se espalha a semente da insurreição e das facções, pondo assim o governo em perigo" (SF, AA 07: 34).

${ }^{12}$ Cf. "arrisco-me a propor se não seria bom, após o cumprimento da instrução acadêmica na teologia bíblica, acrescentar sempre para conclusão, como necessário para o completo equipamento do candidato, um curso especial sobre a pura doutrina filosófica da religião (que utiliza tudo, inclusive a Bíblia), segundo um fio condutor como, por exemplo, este livro (ou também outro, se se conseguir dispor de outro melhor da mesma índole)" $R G V$, AA 06: 10 .

${ }^{13}$ Cf. "Exigir a universalidade para uma fé eclesial (catholicismus hierarchicus) é uma contradição, porque a universalidade incondicionada pressupõe necessidade, a qual só tem lugar onde a própria razão fornece um fundamento (...)" (SF, AA 07, 49) Na sequencia Kant fala que a fé racional poderia ser universalizada, mas por fé racional se exclui toda referência a questões históricas, algo que é central para as religiões históricas, e em segundo lugar, ainda que a fé racional seja universalizável, ela não envolve obrigação, por isso o que Kant está dizendo é que ela poderia se tornar universal, mas não que ela deva se tornar universal, afinal, em questões de crença, não há nenhum tipo de obrigação.

${ }^{14}$ Aqui vale a pena citar o seguinte excerto da Religião nos limites da simples razão: "Não há numa religião universal nenhum dever particular para com Deus; pois Deus nada de nós pode receber, não podemos agir nem sobre Ele nem para Ele. Se da reverência que lhe é devida se pretender fazer semelhante dever, não se tem conta que esta reverência não é uma ação particular de religião, mas a disposição de ânimo religiosa em todas as nossas ações conformes ao dever em geral. Se se disser: 'Importa obedecer mais a Deus do que aos homens", isto significa apenas que: se mandamentos estatutários, a cujo respeito os homens podem ser legisladores e juízes, entrem em conflito com deveres que a razão incondicionalmente prescreve e sobre cujo seguimento ou transgressão somente Deus pode ser juiz, a autoridade daqueles deve ceder perante a destes. Mas se por aquilo em que se deve obedecer mais a Deus do que ao homem se pretendesse entender os mandamentos estatutários de Deus feitos passar por tais por um Igreja, então, tal princípio facilmente se poderia transformar no grito de guerra, muito ouvido, de clérigos hipócritas e ávidos de poder à insurreição contra a autoridade civil. Com efeito, o lícito que esta última ordena é decerto dever: que porém, algo em si lícito, mas a nós cognoscível só por revelação divina seja de facto ordenado por Deus é (pelo menos, na maior parte dos casos) sumamente incerto" $(R G V, \mathrm{AA} 06: 154)$.

${ }^{15}$ Sobre a concepção kantiana de filosofia e sua oposição ao misticismo ver meu artigo... 


\section{Referência bibliográfica:}

HENRICH, D. Zu Kants Begriff der Philosophie. In: KAULBACH, Friedrich; RITTER, Joachim (Hrgs.). Kritik und Metaphysik (Festschrift für Heinz Heimsoeth), Berlin: de Gruyter, 1966, 40-59.

KANT, I. Gesammelte Schriften. Hrsg.: Bd. 1-22 Preussische Akademie der Wissenschaften, Bd. 23 Deutsche Akademie der Wissenschaften zu Berlin, ab Bd. 24 Akademie der Wissenschaften zu Göttingen. Berlin 1900ff.

. Beantwortung der Frage: Was ist Aufklärung? [WA] Trad. Artur Morão. In: A paz perpétua e outros opúsculos. Lisboa: Edições 70, 2004.

. Der Streit der Fakultäten. [SF] Trad. Artur Morão. In: A paz perpétua e outros opúsculos. Lisboa: Edições 70, 1993. 2005 .

Die Metaphysik der Sitten. [MS] Trad. José Lamego. Lisboa: Calouste Gulbenkian,

. Die Religion innerhalb der Grenzen der bloßen Vernunft. [RGV] Trad. Artur Morão. Lisboa: Edições 70, 1992.

Ende aller Dinge. [EaD] Trad. Artur Morão. In: A paz perpétua e outros opúsculos. Lisboa: Edições 70, 1993.

Grundlegung zur Metaphysik der Sitten. [GMS]. Trad. Paulo Quintela. In: Kant II (Coleção os pensadores). São Paulo: Abril Cultural, 1980.

Kritik der reinen Vernunft. [KrV]. Trad. da edição B de Valerio Rohden e Udo Baldur Moosburger. In: Kant I (Coleção os pensadores). São Paulo: Abril Cultural,1980.

Kritik der Urteilskraft. $(K U)$ Trad.Valerio Rohden e António Marques. 2.ed. Rio de Janeiro: Forense Universitária, 2002.

. Logik (Jäsche). [Log] Trad. Guido Antônio de Almeida. 2.ed. Rio de Janeiro: Tempo Brasileiro, 1999.

. Über den Gemeinspruch: Das mag in der Theorie richtig sein, taugt aber nicht für die Praxis. [TP] Trad. Artur Morão. In: A paz perpétua e outros opúsculos. Lisboa: Edições 70, 2004.

. Über das Mißlingen aller philosophischen Versuche in der Theodicee. [MpVT] Bd. 8

. Vorlesungen über Moralphilosophie. [V.MoCollings]. Bd. 27.

. Was heißt: Sich im Denken Orientiren? [WDO] Trad. Artur Morão. In: A paz perpétua e outros opúsculos. Lisboa: Edições 70, 2004. 
Zum ewigen Frieden. [ZeF] Trad. Artur Morão. In: A paz perpétua e outros opúsculos. Lisboa: Edições 70, 2004. 